\title{
DON'T DIE! HOW BIOSIMILAR DISPARAGEMENT VIOLATES ANTITRUST LAW
}

\author{
Michael A. Carrier
}

\begin{abstract}
Competition is the key to low prices in the pharmaceutical industry. For decades, Americans have benefitted from affordable generic versions of brand-name drugs. But now, we stand poised on the wave of a revolution. Biologics, which include lifesaving, cancer-treating drugs, can cost hundreds of thousands of dollars per year and are forecast to be the "fastest growing segment of drug spending" in coming years.

The hope, then, is that just like generic drugs, competition from followon products known as biosimilars will lower prices. But the fear is that they will not. Why? One main reason is disparagement.

Biosimilars are nearly the same as biologics. In fact, they are required to be "highly similar" to, and have "no clinically meaningful differences" from, biologics. Despite this, biologic manufacturers have raised ominous warnings that biosimilars are not the same as biologics but have differences that pose grave safety consequences. Doctors are getting the message loud and clear and are refusing to prescribe appropriate - and more affordablebiosimilars. It thus comes as no surprise that government agencies have serious concerns about the behavior of biologic companies.

This Essay addresses biologic manufacturers' disparagement of biosimilars. It sketches the background of the industry and introduces the unique regulatory setting. It then sets forth the caselaw and explains how disparagement can violate antitrust law.
\end{abstract}

AUTHOR-Distinguished Professor, Rutgers Law School. I would like to thank Tom Cotter, Shubha Ghosh, Elizabeth Jex, Carl Minniti, and Rebecca Tushnet for their helpful comments. 


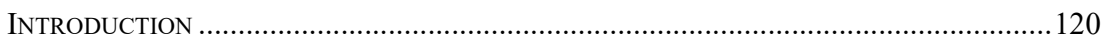

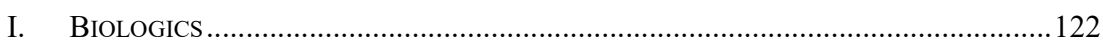

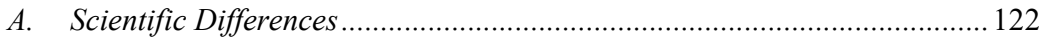

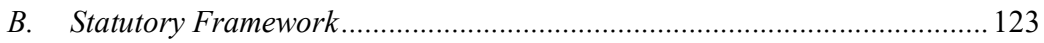

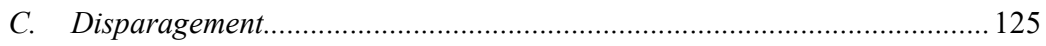

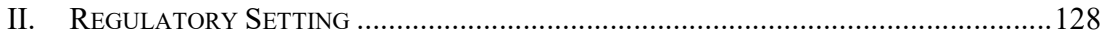

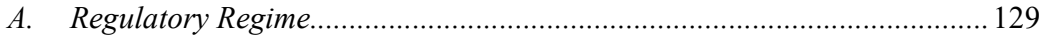

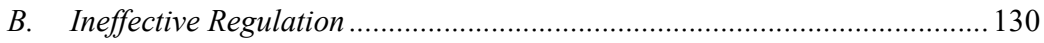

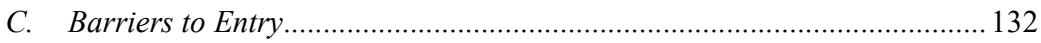

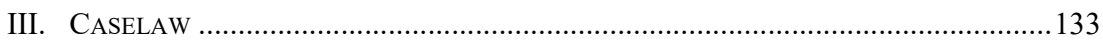

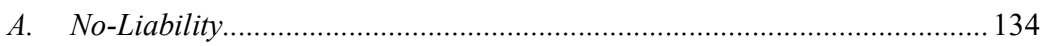

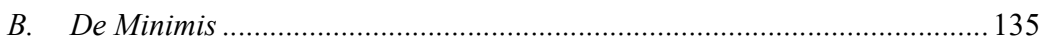

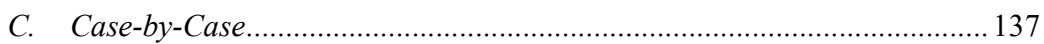

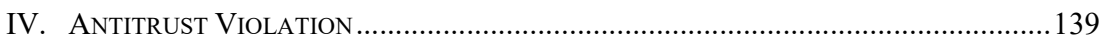

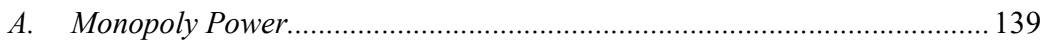

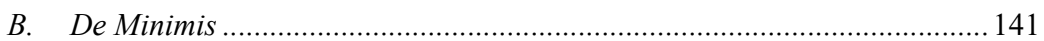

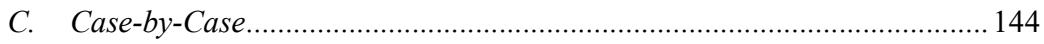

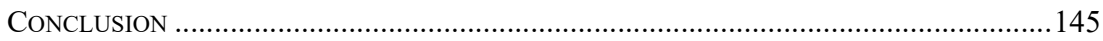

\section{INTRODUCTION}

Competition is the key to low prices in the pharmaceutical industry. For decades, Americans have benefitted from affordable generic versions of brand-name drugs. But now, as biologics enter the market, we stand on the precipice of a revolution. In fact, biologics, which can cost patients hundreds of thousands of dollars per year, are predicted to be the "fastest growing segment of drug spending in the coming years."

The hope, then, is that competition from follow-on products, known as biosimilars, will lower prices for patients. But pharmaceutical companies' campaign of biosimilar disparagement threatens to block this goal.

\footnotetext{
${ }^{1}$ Brian K. Chen, Y. Tony Yang \& Charles L. Bennett, Why Biologics and Biosimilars Remain So Expensive: Despite Two Wins for Biosimilars, the Supreme Court's Recent Rulings Do Not Solve Fundamental Barriers to Competition, DRUGS (Nov. 16, 2018), 1777, 1777 https://www.ncbi.nlm.nih.gov/pubmed/30446980 [https://perma.cc/U2BW-48GU]; Press Release, Scott Gotlieb, Remarks from FDA Commissioner Scott Gottlieb, M.D., as Prepared for Delivery at the Brookings Institution on the Release of the FDA's Biosimilars Action Plan (July 18, 2018), https://www.fda.gov/news-events/press-announcements/remarks-fda-commissioner-scott-gottlieb-mdprepared-delivery-brookings-institution-release-fdas [https://perma.cc/4BWT-TJFD] [hereinafter Remarks from FDA Commissioner].
} 
Biologics are large, complex molecules derived from living organisms, most commonly proteins. ${ }^{2}$ According to the FDA, biologics "often represent the cutting-edge of biomedical research and, in time, may offer the most effective means to treat a variety of medical illnesses and conditions" that have "no other treatments available." ${ }^{3}$ Monoclonal antibodies, the most frequently developed type of biologic, ${ }^{4}$ include blockbuster products such as infection-reducing Neulasta, ${ }^{5}$ as well as Humira ${ }^{6}$ and Remicade, ${ }^{7}$ both of which treat arthritis, colitis, and Crohn's disease. In targeting unhealthy cells without harming healthy cells, ${ }^{8}$ monoclonal antibodies have dramatically increased survival rates. ${ }^{9}$ Other types of biologics include vaccines, blood products, and gene therapies. ${ }^{10}$

Biosimilars are legally required to be "highly similar" to, and have "no clinically meaningful differences" from, biologics." Despite this requirement, biologic manufacturers have warned physicians and patients that the products are not the same, intimating that the differences pose grave safety concerns. And physicians are listening, refusing to prescribe appropriate and affordable biosimilars. ${ }^{12}$ It thus comes as no surprise that government agencies, like the Food and Drug Administration (FDA) and the Federal Trade Commission (FTC), have raised "serious concerns about false

2 Michael A. Carrier \& Carl J. Minniti III, Biologics: The New Antitrust Frontier, 2018 U. ILL. L. REV. 1, 5 (2018); What Are "Biologics" Questions and Answers, FDA, https://www.fda.gov/about$\mathrm{fda} /$ center-biologics-evaluation-and-research-cber/what-are-biologics-questions-and-answers [https://perma.cc/2TGQ-Q3CQ].

3 What Are "Biologics" Questions and Answers, supra note 2.

4 One report concluded that 338 of the 907 biologics in development were monoclonal antibodies. PhRMA, MEDICINES IN DEVElopment: Biologics 4 (2013), http:/phrmadocs.phrma.org/sites/default/files/pdf/biologicsoverview2013.pdf [https://perma.cc/WA4A-74F5].

5 NEULASTA, https://www.neulasta.com/ [https://perma.cc/EL8D-F9UK].

6 HuMIRA, https://www.humira.com/?cid=ppc_ppd_msft_franchise_brand_2015_humira_Exact_64 X1790908 [https://perma.cc/SQ52-8VY2].

7 REMICADE, https://www.remicade.com/?utm_source=bing\&utm_medium=cpc\&utm_campaign $=$ Branded\&utm_content $=$ RAIS $\% 20-\% 20$ General\&utm_term $=$ remicade\&gclid $=$ CJnFzq2_hNICFSi2gQ od1FgEaQ\&gclsrc=ds [https://perma.cc/J3X6-JYSS].

${ }^{8}$ How Targeted Therapies Are Used to Treat Cancer, AM. CANCER SOC'Y, https:/www.cancer.org/treatment/treatments-and-side-effects/treatment-types/targeted-therapy/whatis.html [https://perma.cc/334L-KHUA].

9 For example, the development of Rituxan in the 1990s substantially improved the treatment of nonHodgkin's lymphoma, the most common form of blood cancer in adults. Efrat Dotan, Charu Aggarwal \& Mitchell R. Smith, Impact of Rituximab (Rituxan) on the Treatment of B-Cell Non-Hodgkin's Lymphoma,

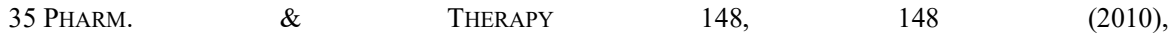
https:/www.ncbi.nlm.nih.gov/pmc/articles/PMC2844047/\#!po=23.6842 [https://perma.cc/S6SE-26BK] (supplementing chemotherapy regimens with Rituxan improved patients' survival rate from 57\% to $70 \%$ in one study).

10 What Are "Biologics" Questions and Answers, supra note 2.

1142 U.S.C. \$ 262(i)(2) (2012).

12 See infra notes 165-172 and accompanying text. 
or misleading statements and their negative impacts on public health and competition."13

This Essay addresses biologic companies' disparagement of biosimilars. Part I sketches the background of the industry, and Part II discusses its unique regulatory setting. Part III then sets forth the caselaw, while Part IV explains how, under two separate approaches, disparagement can violate antitrust law.

\section{BIOLOGICS}

The relationship between biologics and biosimilars differs from that between brand-name drugs and their generic counterparts. This Part sketches these differences and discusses the relevant statute for biologics and biosimilars, as well as biologic companies' disparagement of biosimilars.

\section{A. Scientific Differences}

The science underlying biologics and small-molecule (brand) drugs is different. Small molecules are created through a series of chemical reactions known as chemical synthesis. ${ }^{14}$ The process is predictable, which allows generics to cheaply imitate brand drugs. ${ }^{15}$ Put another way, brands and generics can put the same pieces of a puzzle together in the same way to create the same image. Biologics, in contrast, emphasize not the individual pieces of the puzzle but the way the puzzle is constructed. Because "the product is the process," and the use of living cells to create biologics is inherently sensitive, there is higher variability in the product's final form. ${ }^{16}$

This variability presents challenges to biosimilar manufacturers. Even if these entities can rely on patent disclosures and other materials in the public domain, they will lack access to critical information that is protected as a trade secret. ${ }^{17}$ Because biologics are "so closely defined by their manufacturing process," this secrecy blocks competition. ${ }^{18}$ All of these

\footnotetext{
13 U.S. Food \& Drug Admin. \& Fed. TRade Comm'n, Joint Statement of the Food \& Drug ADMINISTRATION AND THE FEDERAL TRADE COMMISSION REGARDING A COLLABORATION TO ADVANCE COMPETITION IN THE BIOLOGIC MARKETPLACE 3 (Feb. 3, 2020), https://www.ftc.gov/system/files/documents/public_statements/1565273/v190003fdaftcbiologicsstatem ent.pdf [https://perma.cc/Y4YS-HMKQ] [hereinafter JOINT STATEMENT].

14 See Laurence A. Borden, Pharmaceutical and Biotech Patent Law §§ C:5.1, C:5.2 (2020).

15 See infra note 85 and accompanying text.

16 James T. O'ReILly \& KATHARINE A. VAN TASSEl, FOOD AND DRUg ADMINISTRATION § 13:135 (4th ed. 2020). For a discussion of changes during the product's maturation and uncertainties in the structure of a protein (a typical biologic), see Michael A. Carrier \& Carl J. Minniti III, Biologics: The New Antitrust Frontier, 2018 U. ILL. L. REV. 1, 7-8 (2018).

17 W. Nicholson Price II, Regulating Secrecy, 91 WASH. L. REV. 1769, 1793-94 (2016).

${ }^{18} I d$. at 1794.
} 
development difficulties minimize the price reductions that biosimilars can unleash in comparison to generics.

\section{B. Statutory Framework}

The framework statute for biologics, the Biologics Price Competition and Innovation Act (BPCIA), ${ }^{19}$ was designed to encourage innovation and competition. To foster innovation, it provides biologic drugs with two exclusivity periods. ${ }^{20}$ The first period begins when the biologic (known as the reference product) is approved and lasts for four years. ${ }^{21}$ During this period, the FDA will not accept an application from a biosimilar manufacturer. ${ }^{22}$ In the second period, even after the FDA can accept a biosimilar application, it cannot grant approval until twelve years after the date the biologic was first licensed. ${ }^{23}$ This 12 -year exclusivity period gives biologic products strong protection in the marketplace.

The BPCIA fosters follow-on competition through an abbreviated approval pathway for biosimilars. ${ }^{24}$ To gain approval as a biosimilar under the BPCIA, an applicant must show that

the biological product is highly similar to the reference product notwithstanding minor differences in clinically inactive components; and [] there are no clinically meaningful differences between the biological product and the reference product in terms of the safety, purity, and potency of the product. ${ }^{25}$

A biosimilar manufacturer can show that its product is highly similar to the reference product by "extensively analyzing... the structure and function" of both products. ${ }^{26}$ The FDA has made it clear that "[m]inor differences ... in clinically inactive components are acceptable," with the agency "carefully evaluat[ing]" such disparities to ensure that the biosimilar "meets FDA's high approval standards." ${ }^{27}$ In fact, "slight differences" are expected during the manufacturing process, not only for biosimilars but also

\footnotetext{
19 Biologics Price Competition and Innovation Act of 2009, Pub. L. No. 111-148, 124 Stat. 804 (2010).

2042 U.S.C. $\S 262(\mathrm{k})(7)(2012)$.

${ }^{21} I d . \S 262(\mathrm{k})(7)(\mathrm{B})$.

${ }^{22} I d$.

${ }^{23} I d . \S 262(\mathrm{k})(7)(\mathrm{A})$.

${ }^{24} I d . \S 262(\mathrm{k})$.

${ }^{25}$ Id. § 262(i)(2) (emphasis added).

${ }^{26}$ Biosimilar and Interchangeable Products, FDA,

https://www.fda.gov/drugs/biosimilars/biosimilar-and-interchangeable-products [https://perma.cc/BHW 4-YU4W].

${ }^{27} I d$.
} 
for biologics. As one company has explained, "most biologics vary and . . . in fact are not identical batch-to-batch. . .." 28

A biosimilar manufacturer's ability to make these showings assuages fears that its product is not as safe as the biologic. A coalition of nearly thirty pharmaceutical regulators from around the world has explained that biosimilars demonstrate similarity through "extensive laboratory comparability studies." 29 These studies use "highly sensitive state-of-the-art analytical technology that allows robust and extensive examination and comparison of the biosimilar and originator molecules." 30

The benefits of obtaining follow-on approval under the BPCIA differ from those under the Hatch-Waxman Act, Congress's framework statute for competition and innovation in the small-molecule, or brand-drug, setting. ${ }^{31}$ Unlike the Hatch-Waxman regime, in which the first generic manufacturer to file what is known as a "Paragraph IV" certification (claiming that the brand's patent is invalid or not infringed ${ }^{32}$ ) is eligible for a 180-day period of exclusivity, the first to file a biosimilar does not benefit from such protection. ${ }^{33}$ Rather, exclusivity is granted only to the first biosimilar that clears the higher threshold of interchangeability. ${ }^{34}$

To attain interchangeability status, the applicant must show that the follow-on version (1) "is biosimilar to the reference product" and (2) "can be expected to produce the same clinical result as the reference product in any given patient." ${ }^{35}$ For products administered more than once to an individual, the follow-on maker must show that the risk of switching between products is not greater than the risk of not switching. ${ }^{36}$ If the applicant seeking interchangeability can meet this standard, it will receive exclusivity, which expires (if certain other litigation or approval thresholds are not

\footnotetext{
${ }^{28}$ Boehringer Ingelheim, Comment Letter on Pfizer's Citizen Petition to FDA, Docket \# FDA-2018P-3281, at 3 (Jan. 25, 2019) [hereinafter Boehringer Letter] (on file with author).

${ }^{29}$ ICMRA Statement about Confidence in Biosimilar Products (for Healthcare Professionals), INT'L COALITION MEDS. Reg. AUTHORITIES, http://www.icmra.info/drupal/sites/default/files/201907/ICMRA_statement_about_confidence_in_biosimilar_product_HCP.PDF [https://perma.cc/YKB6$\mathrm{P} 4 \mathrm{KF}]$.

${ }^{30} \mathrm{Id}$.

31 Drug Price Competition and Patent Term Restoration Act of 1984, 21 U.S.C. $\S 355$ (2012).

32 Id. $\S 355(\mathrm{j})(2)(\mathrm{A})(\mathrm{vii})(\mathrm{IV})$.

3342 U.S.C. $\S 262(\mathrm{k})(6)(2012)$.

34 Id. The standard of "interchangeability" is defined in the statute and is not the same as the use in common discourse of being substitutable. See id. $\$ 262(\mathrm{k})(2)$ (defining interchangeability).

${ }^{35} I d . \S 262(\mathrm{k})(4)(\mathrm{A})(\mathrm{i})-(\mathrm{ii})$.

${ }^{36} I d$. $262(\mathrm{k})(4)(\mathrm{B})$.
} 
reached earlier) one year after commercial marketing. ${ }^{37}$ The FDA has not yet approved an interchangeable biosimilar. ${ }^{38}$

\section{Disparagement}

In the small-molecule setting, disparagement is not a concern. Brands are not likely to falsely injure near-identical generics, which garner sales not from advertising campaigns but from state laws that allow-and in many cases require - pharmacists to substitute generic versions of brand-name prescriptions. ${ }^{39}$ In contrast, the education of stakeholders is critical to the marketing of biologics and biosimilars ${ }^{40}$ which has tempted biologic firms to engage in disparagement.

There are four related categories of statements and omissions that biologic firms have made against biosimilars, none of which is consistent with the statute. The first category is the most dramatic. A January 2019 Washington Post article quotes Philip Schneider, chairman of the Alliance for Safe Biologic Medicines' international advisory board, as suggesting caution in a move to unbranded biologics "so we don't end up with another thalidomide [which famously caused birth defects]" or "all the other things that happen when safety isn't considered." ${ }^{41}$ Offering another example in the fearmongering category, the article further quotes a patient advocate affiliated with the group, who stated that a switch from one drug to another "disrupts your continuity of care," as "[y]ou could end up in an emergency room, or be[] hospitalized, or try[] other, less efficient treatments," all of which "can exacerbate or flare your disease, bring[ing] it out of remission." 42

37 Id. $\S 262(\mathrm{k})(6)$ (specifying that exclusivity expires on earliest of one year after commercial marketing, 18 months after court judgment or dismissal in patent litigation, 42 months after approval if litigation pending, or 18 months after approval if applicant has not sued).

${ }^{38}$ Biosimilar and Interchangeable Biologics: More Treatment Choices, FDA, https://www.fda.gov/consumers/consumer-updates/biosimilar-and-interchangeable-biologics-moretreatment-choices [https://perma.cc/CBD5-KYF6].

39 See Michael A. Carrier, A Real-World Analysis of Pharmaceutical Settlements: The Missing Dimension of Product Hopping, 62 FLA. L. REv. 1009, 1017 (2010); Brad Weltman, Why Pharmaceutical Advertising Is Virtually Absent from the Web, ADWEEK (Nov. 2, 2016), http://www.adweek.com/news/advertising-branding/why-pharmaceutical-advertising-virtually-absentweb-174393 [https://perma.cc/83XC-KA9H].

40 See Awareness of Biosimilars Among U.S. Specialty Physicians Is High but New Survey Identifies Five Major Knowledge Gaps, BIOsimilar Dev. (Nov. 1, 2016), https://www.biosimilardevelopment.com/doc/awareness-biosimilars-specialty-physicians-surveyidentifies-knowledge-gaps-0001 [https://perma.cc/7SS5-SHMV].

${ }^{41}$ Christopher Rowland, 'Marketers Are Having a Field Day': Patients Stuck in Corporate Fight Against Generic Drugs, WASH. Post (Jan. 9, 2019, 8:00 PM), https://www.adweek.com/brandmarketing/why-pharmaceutical-advertising-virtually-absent-web-174393/ [https://perma.cc/LR4WTP5K].

${ }^{42} I d$. 
The second group of assertions claims that the biosimilar acts differently from the reference product. In an Amgen YouTube video quoted in Pfizer's citizen petition raising awareness of this issue, the company states that the two products "can behave differently in the body." ${ }_{43}$ Amgen also tweeted: "Biologics or biosimilars? It's not just apples to apples. While \#biosimilars may be highly similar to their \#biologic reference products, there's still a chance that patients may react differently."44 Janssen Biotech provides a similar, albeit more subtle, example. In a patient brochure, the company states that a patient "may be asked to switch to a biosimilar that works in a similar way to REMICADE," but that "you and your doctor did a lot of fine tuning to get where you are now," so "if your REMICADE® treatment is still working for you, talk to your doctor about staying on it." 45

The third category is based on claims that the biosimilar is not identical to the reference product. The Amgen video mentioned above states that "no two biologic medicines are identical." 46 Similarly, Genentech's website, again as discussed in the Pfizer citizen petition, states that "FDA requires a biosimilar to be highly similar, but not identical" to the reference product. ${ }^{47}$

The fourth group emphasizes that biosimilars do not satisfy the standard of interchangeability. In the brochure mentioned above, Janssen states that "[e]ven though infliximab biosimilars are very similar to REMICADE®, that doesn't mean they are interchangeable with REMICADE®." Janssen also warned (in bolded statements) that "no infliximab biosimilar has been proven to be interchangeable with REMICADE $\AA$ " and that "[t]he infliximab biosimilars are not approved as interchangeable with REMICADE®." 48

Each of these four categories can constitute disparagement. The firstconsisting of threatening comparisons to Thalidomide and warnings of trips to the emergency room-needs no explanation. But each of the other categories also runs afoul of the statute's requirements. The second category - that the biosimilar acts differently - fails to mention that the FDA only approves a biosimilar when it is "highly similar" to and has "no clinically meaningful differences" from the biologic product. ${ }^{49}$ In other words, the biologic and biosimilar products are required to have the same

43 Pfizer InC., Citizen PetiTion to FDA 8 (Aug. 22, 2018), https://www.bigmoleculewatch.com/ wp-content/uploads/sites/2/2018/08/Citizen_Petition_from_Pfizer.pdf [https://perma.cc/3YCG-5LN7].

${ }^{44} I d$. at 7.

45 Id. at 8; Janssen Immunology, Remicade Infliximab Brochure (on file with author).

46 Citizen Petition to FDA, supra note 43 (citation omitted).

${ }^{47}$ Id.; Biosimilars vs. Generics: What is the Difference?, EXAMINE BIOSIMILARS, https://www.examinebiosimilars.com/content/examinebiosimilars/en_us/biosimilars-vs-generics.html [https://perma.cc/DX9R-Z8GH] (internal citation omitted).

48 Remicade Infliximab Brochure, supra note 45; Citizen Petition to FDA, supra note 43, at 8.

4942 U.S.C. § 262(i)(2). 
safety and effectiveness profile. ${ }^{50}$ As the FDA explained in Draft Guidance issued in February 2020, "representations or suggestions that create an impression that a biosimilar is not highly similar to its reference product are likely to be false or misleading." ${ }_{51}$

Evidence from Europe, which has witnessed robust biosimilar market entry, has confirmed that more than "700 million patient days of treatment" demonstrated that "clinical outcomes with biosimilars match the outcomes of the reference biologics." ${ }_{52}$ This evidence also has revealed that "patient[s] switching from the reference biologic to the biosimilar . . . is not of concern" since more than 14,000 switches resulted in "[n]o change in clinical outcomes." ${ }^{3}$ As discussed below, ${ }^{54}$ disparaging statements, even if not completely false, are, at a minimum, deceptive in conveying the misleading interpretation that biosimilars have "clinically meaningful differences" from their reference biologics. ${ }^{55}$

The third category - claiming that the biosimilar is not identicalfocuses on an issue that is irrelevant; in fact, it is "normal and expected within the manufacturing process" for even batches of biologic products themselves to reveal "[s]light differences." 56 In the Draft Guidance mentioned above, the FDA "remind[ed] firms that a biosimilar product is not required to be identical to the reference product" but that it need only be "highly similar to the reference product notwithstanding minor differences in clinically inactive components and that there are no clinically meaningful differences ... in terms of safety, purity, and potency." ${ }^{57}$

Finally, for the fourth category, a biosimilar's failure to attain interchangeability does not mean that it is less safe. For starters, this status only makes sense for biosimilars that will be dispensed at the pharmacy

\footnotetext{
${ }^{50}$ Patient $\quad$ Materials, FDA, https://www.fda.gov/drugs/biosimilars/patient-materials [https://perma.cc/AHW4-NJXF].

51 U.S. Food \& Drug Admin., Promotional Labeling AND AdVERTISING CONSIDERATIONS FOR PRESCRIPTION BIOLOGICAL REFERENCE AND BIOSIMILAR PRODUCTS QUESTIONS AND ANSWERS: DRAFT GUIDANCE FOR INDUSTRY 6 (Feb. 2020), https://www.fda.gov/regulatory-information/search-fdaguidance-documents/promotional-labeling-and-advertising-considerations-prescription-biologicalreference-and-biosimilar [https://perma.cc/LHL9-KQWF] [hereinafter PROMOTIONAL LABELING AND ADVERTISING CONSIDERATIONS].

52 Biosimilars Forum, Structural Market Changes Needed in U.S. to Achieve Cost$\begin{array}{llllll}\text { SAVINGS } & \text { FROM } & \text { BIOSIMILARS } & 8 & \text { (Mar. } & 19,\end{array}$ http://biosimilarsforum.org/PDF/BIosimilars_WhitePaper-final.pdf [https://perma.cc/QV4L-DEPV].

${ }^{53} \mathrm{Id}$.

54 See infra notes 151-156 and accompanying text.

5542 U.S.C. § 262(i)(2) (defining biosimilars as having no clinically meaningful differences).

${ }^{56}$ U.S. Food \& Drug Admin., Biological Product Definitions 1, https://www.fda.gov/files/drugs/published/Biological-Product-Definitions.pdf [https://perma.cc/7RWASZYX].

57 Promotional Labeling And Advertising Considerations, supra note 51, at 7-8.
} 
counter (where substitution takes place), but each of the 15 biosimilars that has entered the U.S. market is dispensed in a hospital or infusion center. ${ }^{58}$ More fundamentally, as Pfizer pointed out in its citizen petition, its biosimilar "demonstrated that a single switch does not result in different safety or efficacy." ${ }^{59}$ As the statement from the global regulatory authorities explained, "[a] full clinical development program[] is not necessary when extensive laboratory testing has demonstrated that the biosimilar is highly similar to the originator." ${ }_{00}$ And as Boehringer Ingelheim explained in supporting Pfizer's petition, "an FDA interchangeability designation is irrelevant" for "the majority of biologics . . . administered to the patient by the physician who has written the prescription," with "misinformation ... generated" to "impl[y] that interchangeable biologics are "better biosimilars' . . rather than the same biosimilar on which additional data has been generated." 61

\section{REGULATORY SETTING}

How should courts analyze the antitrust effects of biologic firms' disparagement of biosimilars? This Part sets the stage for the antitrust analysis by discussing the importance of the regulatory regime, showing the regime's ineffectiveness, and highlighting the significant barriers to entry facing biosimilars.

By brief way of background, the antitrust framework that applies to a single firm acting unilaterally is monopolization. This offense requires a showing of monopoly power and exclusionary conduct. ${ }^{62}$ Monopoly power is "the power to control prices or exclude competition." ${ }^{63}$ Biologic firms that disparage biosimilars are likely to satisfy this element because of their ability

58 Sean McGowan, Five Years On, Biosimilars Need Support From All Health Care Players, STAT (Mar. 6, 2020), https://www.statnews.com/2020/03/06/biosimilars-in-us-turn-five/ [https://perma.cc/ 4LMG-BDJR]; see Patient Materials, supra note 50; Ana Rose Welch, Biosimilars and the Site of Care: Current Considerations, BIosimiLAR Dev. (Mar. 26, 2019), https://www.biosimilardevelopment.com/ doc/biosimilars-and-the-site-of-care-current-considerations-0001 [https://perma.cc/8RZN-QXXT].

59 See Citizen Petition to FDA, supra note 43, at $8 \mathrm{n} .34$ (citing clinical trials sponsored by the Norwegian government).

60 ICMRA Statement, supra note 29 (finding that when a biosimilar is "highly similar" to the originator it can be "approved for the same indications as the originator on the basis of the established efficacy and safety of the originator").

61 See Boehringer Letter, supra note 28, at 5.

62 See, e.g., United States v. Grinnell Corp., 384 U.S. 563, 570-71 (1966).

63 United States v. E.I. du Pont de Nemours \& Co., 351 U.S. 377, 391 (1956). 
to charge and sustain supracompetitive prices in a market characterized by significant barriers to entry. ${ }^{64}$

In contrast to monopoly power, the caselaw on exclusionary conduct is less clear. Courts often distinguish between the "willful acquisition or maintenance of [monopoly] power" and "growth or development as a consequence of a superior product, business acumen, or historic accident." 65 Considering the regulatory regime can shed critical light on the issue of exclusionary conduct.

\section{A. Regulatory Regime}

As the Supreme Court explained in Verizon Communications v. Trinko, the starting point for antitrust analysis is the regulatory regime. The Court stated that antitrust analysis must take "careful account" of "the pervasive federal and state regulation characteristic of the industry" and "recognize and reflect the distinctive economic and legal setting of the regulated industry to which it applies." ${ }_{66}$

The Court in Trinko considered not just the existence of a regulatory regime, but also its effectiveness. In Trinko, the regime was working: phone companies providing local service were required to "be on good behavior" and not to discriminate in providing access before entering the long-distance market. ${ }^{67}$ Firms that did not satisfy these conditions were subject to financial penalties, weekly reporting requirements, or the suspension or revocation of long-distance approval. ${ }^{68}$

In contrast, regulatory abuse has prevented the biologics regime from operating as intended. The combination of ineffective FDA regulation and high barriers to entry ensures a role for antitrust. ${ }^{69}$

\footnotetext{
${ }^{64}$ Such price increases offer direct proof of monopoly power. Courts also consider indirect proof in the form of a defendant's share of the relevant market. See, e.g., In re Nexium (Esomeprazole) Antitrust Litig., 968 F. Supp. 2d 367, 388 n.19 (D. Mass. 2013) (finding "direct evidence of market power" in allegations that brand firm "had the power to maintain the price of the drug . . . at supracompetitive levels without losing substantial sales to other products" and that the drug "enjoyed high barriers to entry").

65 Grinnell, 384 U.S. at 570-71.

66 Verizon Comm. Inc. v. Trinko, 540 U.S. 398, 411 (2004) (internal citations omitted).

$67 \mathrm{Id}$. at 412.

${ }^{68} I d$. at 413 .

${ }^{69}$ See Herbert Hovenkamp, FRAND and Antitrust, 105 CORNELl L. REv. 101, 140 (2020) ("Many federal antitrust violations are also breaches of contract, torts, or violations of some other body of law ... [and] [t] he remedy in these cases is not to dismiss one or the other claim ....").
} 


\section{B. Ineffective Regulation}

Biosimilar competition in the United States is far from robust. In Europe, 59 biosimilars have received approval. ${ }^{70}$ In the United States, 27 biosimilars have been approved (with more than half the approvals occurring since July 2018). ${ }^{71}$ In addition, U.S. biosimilars have offered savings of only $15 \%$ to $35 \%$ (typically on the lower end), far less than the more significant (often $70 \%$ ) discounts in Europe. ${ }^{72}$

The weak U.S. biosimilar market is not the consequence of the FDA's lack of effort. In its citizen petition, Pfizer pointed to "various initiatives" the agency had undertaken "aimed at encouraging and facilitating the development and approval of biosimilars." "73 Such activities included "the numerous biosimilar-related guidance documents FDA has issued, the Agency's development and distribution of educational materials ..., the Agency's Biosimilar User Fee Act performance goals, and the... Biosimilars Action Plan." 74

Despite these efforts, FDA officials have expressed frustration with the lack of biosimilar competition. In 2018, Former Commissioner Scott Gottlieb "worried" that the market for biosimilars "still isn't established" and that " $[\mathrm{t}]$ he ability for these products to penetrate clinical practice, and gain acceptance, is still not firm." 75 In addition, Gottlieb lamented that biosimilar

70 Aydin Harston, How the U.S. Compares to Europe on Biosimilar Approvals and Products in the Pipeline, Rothwell FIGG (May 7, 2019), https://www.biosimilarsip.com/2019/05/07/how-the-u-scompares-to-europe-on-biosimilar-approvals-and-products-in-the-pipeline-4/ [https://perma.cc/AAY4JRFD].

${ }^{71}$ Biosimilar Product Information, FDA (June 11, 2020), https://www.fda.gov/drugs/biosimilars/biosimilar-product-information [https://perma.cc/ST4Z-H2C6]. Until recently, significantly more biosimilars had entered the market in Europe, but that gap has closed. See Per Troein, Max Newton, Jyoti Patel \& Kirstie Scott, The IMPACt of Biosimilar Competition IN EUROPE, IQVIA 4 (Oct. https://ec.europa.eu/docsroom/documents/38461/attachments/1/translations/en/renditions/native [https://perma.cc/976B-YUVY] (16 biosimilars launched in Europe as of 2018); McGowan, supra note 58 (15 biosimilars marketed in U.S. as of 2020). The European regime differs from the U.S. in various ways, but when given the option, doctors have more frequently prescribed (and patients have more frequently taken) biosimilars. See Samantha DiGrande, European Report Finds Generics and Biosimilars Key to Curbing Wasteful Drug Spending, AJMC (Nov. 27, 2018), https://www.centerforbiosimilars.com/news/european-report-finds-generics-and-biosimilars-key-tocurbing-wasteful-drug-spending [https://perma.cc/P5NP-QWAQ] (noting that certain European countries have incentives for physicians to prescribe biosimilars).

72 Joint Statement, supra note 13, at 2; Ying Chen, Jennifer Dikan, Jennifer Heller \& Jorge Santos da Silva, Five Things to Know About Biosimilars Right Now, MCKInSEY \& Co. (July 17, 2018), https://www.mckinsey.com/industries/pharmaceuticals-and-medical-products/our-insights/five-thingsto-know-about-biosimilars-right-now [https://perma.cc/RFC3-XAR9].

73 Citizen Petition to FDA, supra note 43, at 2.

${ }^{74} \mathrm{Id}$.

75 Remarks from FDA Commissioner, supra note 1. 
competition is "anemic" and that "the real savings" from biosimilars have been "just a fraction of even the most conservative initial estimates." " In fact, the agency found that "if Americans had the opportunity to purchase successfully marketed, FDA-approved biosimilar prescription drugs, they could have saved more than $\$ 4.5$ billion in 2017." 77 Such savings, however, will not come to fruition if biologic companies "unfairly delay or derail the entry of biosimilar competitors" through conduct (discussed in the next Part) such as patent thickets and anticompetitive contracts. ${ }^{78}$ Gottlieb expressed further concern "that the biosimilar manufacturers may pull out" if biologics "are able to lock up markets even in cases where there's a fully interchangeable competitor." 79

Even more on point, Gottlieb "worried" that "there are either deliberate or unintentional efforts by branded companies to create confusion" about biosimilars' safety and effectiveness. ${ }^{80}$ These messages "can potentially undermine consumer confidence in biosimilars in ways that are untrue" and "negatively impact a patient's judgment about an otherwise safe and effective product." 81 The FDA and FTC reiterated these concerns in a joint statement in February 2020 in which they explained that they "support competitive markets for biologics" and "have serious concerns about false or misleading statements and their negative impacts on public health and competition." "82

Compounding the regulatory regime's inability to effectuate robust biosimilar competition is the FDA's failure to (1) approve an interchangeable or (2) explain the lack of safety consequences from the absence of an interchangeability designation. ${ }^{83}$ As the disparagement examples above show, ${ }^{84}$ this vacuum has led to assumptions that biosimilars are unsafe as none have attained the highest standard of substitutability. This misunderstanding fails to recognize that-even if not as much data is

\footnotetext{
${ }^{76} \mathrm{Id}$.

$77 \mathrm{Id}$.

78 Id.

79 Id.

${ }^{80}$ Hillel P. Cohen \& Dorothy McCabe, Combatting Misinformation on Biosimilars and Preparing the Market for Them Can Save the U.S. Billions, STAT (June 19, 2019), https://www.statnews.com/2019/06/19/misinformation-biosimilars-market-preparation/ [https://perma.cc/DE2U-Q7GX].

$81 \mathrm{Id}$.

82 JOINT STATEMENT, supra note 13, at 3.

83 Draft FDA guidance would begin to address this in explaining that "promotional materials for a reference product should avoid representing or suggesting that a biosimilar product is less safe or effective than its reference product because it has not been licensed as interchangeable with the reference product." PROMOTIONAL LABELING AND ADVERTISING CONSIDERATIONS, supra note 51, at 7.

${ }^{84}$ See supra Section I.C.
} 
generated - a finding of biosimilarity is sufficient for patients to have complete confidence that the product is safe and will work as effectively as the reference biologic. For if a biosimilar was any less safe or effective, the FDA never would have approved it in the first place.

\section{Barriers to Entry}

Exacerbating the regulatory regime's ineffectiveness are multiple barriers to entry that have limited the number of U.S. biosimilars, including development costs, patent thickets, anticompetitive contracts, and established patients.

The first barrier to entry is the cost of developing biosimilars. As discussed above, ${ }^{85}$ biosimilar manufacturers face significant development hurdles. Not only are the products complex, but key inputs are also hidden behind trade secrets and opaque manufacturing processes. As a result, unlike generics, which cost an average of $\$ 5$ million to bring to market, biosimilar development involves more intensive and uncertain research and development, which could result in costs of at least $\$ 100$ million. ${ }^{86}$

A second hurdle involves vast patent thickets that biologic companies have put together. For example, AbbVie has more than 100 patents covering anti-inflammatory-treating Humira, including more than 50 obtained in 2015 and 2016 combined, just before the patent on the medicine's active ingredient expired. ${ }^{87}$ Similarly, Johnson \& Johnson (J\&J) has more than 100 patents covering the anti-inflammatory medication Remicade. ${ }^{88}$ Biosimilar manufacturers are not able to get around such massive portfolios. ${ }^{89}$

A third barrier involves an array of conduct by which biologic firms have bundled products, employed exclusive dealing, and used rebates to make it harder for rivals to obtain a foothold in the market. Pfizer described this conduct in its lawsuit challenging J\&J's protection of its biologic

\footnotetext{
85 See supra Section I.A.

86 Biosimilars Forum, QUANTIFying the VAlue OF Biosimilars 2 (2018), http://biosimilarsforum.org/PDFs/Biosims\%20Value\%20Whitepaper\%202018-0614_Revised_20180712.pdf [https://perma.cc/L7WX-R829]; Scott Gottlieb, How Obama's FDA Keeps Generic Drugs Off the Market, 113 Mo. MED. 444, 444 (2016); Henry G. Grabowski, David B. Ridley, Kevin A. Schulman \& Tomas J. Philipson, Entry and Competition in Generic Biologics, 28 MANAGERIAL \& DECISION ECON. 439, 443 (2007).

87 Cynthia Koons, This Shield of Patents Protects the World's Best-Selling Drug, BloOMBERG BUSINESSWEEK (Sep. 7, 2017, 5:00 AM), https://www.bloomberg.com/news/articles/2017-09-07/thisshield-of-patents-protects-the-world-s-best-selling-drug [https://perma.cc/GPW7-VUZ4].

88 Id.

89 See, e.g., Richard GonZalez, AbbVIE Long-Term Strategy 14 (Oct. 30, 2015), http://www.biotechduediligence.com/uploads/6/3/6/7/6367956/abbvie_strategy_presentation_1_.pdf [https://perma.cc/VQ8Y-47HW] (listing categories of drugs making up "Broad U.S. Humira Patent Estate").
} 
Remicade at the expense of Pfizer's rival Inflectra..$^{90}$ Pfizer challenged J\&J's exclusive contracts, made up of (1) "express terms that would exclude biosimilars" from "medical policies and drug formularies" and (2) "fail first" provisions, which "require a patient to first try and fail on Remicade before the insurance company would reimburse Inflectra or another biosimilar." 91 Pfizer also claimed that J\&J "bundled rebates across multiple products," forcing insurers to "pay a higher price on other [J\&J] products" if they "refuse[d] to grant exclusivity to Remicade."

The fourth and final barrier is presented by established patients. These "incontestable patients" "represent inelastic demand" as they are "highly unlikely' to [switch] to a biosimilar," even in response to a price increase..$^{93}$ For that reason, Pfizer challenged J\&J's "all-or-nothing" program, which "bundles the base of existing Remicade patients with new patients." ${ }^{94}$ By "premising rebates on this incontestable population," J\&J sought to use a "rebate trap," forcing insurers to "exclude Inflectra from competing for new patients." 95

The combined effect of these entry barriers exacerbates the problem. The cost of development limits the universe of biosimilars, and patent thickets make it extremely difficult to enter many markets. Existing patients are difficult to move to new medicines-even when they are more affordable. Rebates, bundling, and exclusive dealing threaten to link existing and new patients together. And on top of these existing barriers, disparagement dissuades the remaining new patients, taking away what should be the most receptive segment of the market: those not locked into existing regimens. Before determining if disparagement violates antitrust law, the next Part analyzes the approaches courts have applied to this conduct.

\section{CASELAW}

In analyzing the antitrust effects of disparagement, courts have adopted one of three approaches. This Part discusses the three: no-liability, de minimis, and case-by-case analyses.

\footnotetext{
${ }^{90}$ Pfizer Inc. v. Johnson \& Johnson, 333 F. Supp. 3d 494, 498-99 (E.D. Pa. 2018).

91 Id. Fail first provisions are essentially a form of exclusive dealing since "if a patient fails first on Remicade, it would 'defy sound medical judgment' for a physician to switch to a therapeutic equivalent biosimilar, such as Inflectra, rather than try another therapy." Id.

92 Id. at 499.

93 Id.

${ }^{94} \mathrm{Id}$.

${ }^{95} \mathrm{Id}$.
} 


\section{A. No-Liability}

The first approach, which has been applied by the Fifth and Seventh Circuits, reasons that false statements enhance competition in advertising markets and thus that disparagement-based antitrust claims are not actionable. For example, the Fifth Circuit has drawn a distinction between "business torts, which harm competitors, and truly anticompetitive activities, which harm the market." "96 It has also stated that "absent a demonstration that a competitor's false advertisements had the potential to eliminate, or did in fact eliminate, competition, an antitrust lawsuit will not lie." ${ }^{97}$ Similarly, the Seventh Circuit stated bluntly that "[c]ommercial speech is not actionable under the antitrust laws." 98 In particular, this court asserted that "[a]ntitrust law condemns practices that drive up prices by curtailing output," distinguishing "[f]alse statements about a rival's goods [that] do not curtail output in either the short or long run," but instead "just set the stage for competition in a different venue: the advertising market." 99

This hands-off approach is not persuasive. There is not such a "rigid distinction" between "business torts, which harm competitors, and truly anticompetitive activities, which harm the market." 100 Deceptive statements could depress demand for the criticized product, thereby reducing output and increasing price. ${ }^{101}$ Many false statements are made about the defendant's own products, with false superiority claims discouraging consumers from using any competitor's products. ${ }^{102}$ More fundamentally, misleading advertising forces competitors to fight back on unfair ground, expending resources defending truth against falsehood instead of investing them elsewhere, harming their overall ability to compete. And as Professor Rebecca Tushnet has written, "corrective advertising, especially by an

96 Retractable Techs., Inc. v. Becton Dickinson \& Co., 842 F.3d 883, 895 (5th Cir. 2016).

97 Id.

98 Sanderson v. Culligan Int'l Co., 415 F.3d 620, 624 (7th Cir. 2005).

99 Id. at 623.

100 Shubha Ghosh, The Antitrust Logic of Biologics, 2018 U. ILL. L. REV. ONLINE 46, 53 (2018) (citing Retractable Techs., 842 F.3d at 895).

101 See Kevin S. Marshall, Product Disparagement Under the Sherman Act, Its Nurturing and Injurious Effects to Competition, and the Tension Between Jurisprudential Economics and Microeconomics, 46 SANTA ClARA L. REV. 231, 253 (2006) (finding it "short-sighted to conclude that the intentional dissemination of false information about a rival's product does not constitute a restraint of trade" since it "restrains the autonomous forces of supply and demand, and is therefore injurious to competition").

102 See, e.g., Michael A. Carrier \& Rebecca Tushnet, An Antitrust Framework for False Advertising 106 IowA L. REV. (forthcoming 2021) (manuscript at 3, 11), https://papers.ssrn.com/sol3/papers.cfm?abstract_id=3593914 [https://perma.cc/L2BA-EL2A] (describing AT\&T's false promise of "unlimited" data, which discouraged consumers from using rivals). 
inherently-less-credible-because-self-interested competitor, is unlikely to fix all the damage of false advertising." 103

By engaging in deception, a company - in particular, a monopolistcould entrench its position in the market. And this conduct could (based on the dichotomy drawn in a leading Supreme Court monopolization case) resemble more the "willful acquisition or maintenance of [monopoly] power" than a "superior product, business acumen, or historic accident."104 Or the deception, applying another landmark case, could be viewed as "tend[ing] to impair the opportunities of rivals" and "not further[ing] competition on the merits." 105

\section{B. De Minimis}

The second approach, represented by the Second, Sixth, Ninth, Tenth, and Eleventh Circuits, applies a presumption that the exclusionary effects of disparagement are de minimis. ${ }^{106}$ The plaintiff can rebut such a presumption by showing that the alleged anticompetitive conduct is (1) clearly false, (2) clearly material, (3) clearly likely to induce reasonable reliance, (4) made to buyers without knowledge of the subject matter, (5) continued for prolonged periods, and (6) not readily susceptible to neutralization or other offsets by rivals. ${ }^{107}$ Courts are not consistent on whether a plaintiff must show each of the six factors. ${ }^{108}$

In creating such strict requirements, the framework ensures that the vast majority of false advertising, perpetuated by firms lacking market power, does not automatically violate antitrust law. But it overshoots the mark in making it nearly impossible to find antitrust liability even for monopolists bringing about substantial competitive harm.

103 Rebecca Tushnet, Fifth Circuit Reverses Multimillion-Dollar Antitrust Verdict Based on False Advertising, Remands, REBECCA TUSHNET (Dec. 6, 2016), https://tushnet.com/2016/12/06/fifth-circuitreverses-multimillion-dollar-antitrust-verdict-based-on-false-advertising-remands-2/ [https://perma.cc/5BS7-CQFC].

104 United States v. Grinnell Corp., 384 U.S. 563, 570-71 (1966).

105 Aspen Skiing Co. v. Aspen Highlands Skiing Corp., 472 U.S. 585, 605 n.32 (1985) (quotation omitted). For additional critiques of the no-liability approach, see also Carrier \& Tushnet, supra note 102, at $10-13$.

106 See Duty Free Ams., Inc. v. Estée Lauder Cos., 797 F.3d 1248, 1268-69 (11th Cir. 2015); Lenox MacLaren Surgical Corp. v. Medtronic, Inc., 762 F.3d 1114, 1127-28 (10th Cir. 2014); Am. Council of Certified Podiatric Physicians \& Surgeons v. Am. Bd. of Podiatric Surgery, Inc., 323 F.3d 366, 370 (6th Cir. 2003); Am. Prof'l Testing Serv., Inc. v. Harcourt Brace Jovanovich Legal \& Prof'l Publ'ns, Inc., 108 F.3d 1147, 1152 (9th Cir. 1997); Nat'l Ass'n of Pharm. Mfrs., Inc. v. Ayerst Labs., 850 F.2d 904, 916 (2d Cir. 1988).

${ }^{107}$ Duty Free Ams., 797 F.3d at 1269.

108 See, e.g., Am. Council of Certified Podiatric Physicians \& Surgeons, 323 F.3d at 371 ("We decline to consider each element or hold that all elements must be satisfied to rebut the de minimis presumption."). 
In assessing the appropriateness of the de minimis factors, it is worth considering false advertising law, which offers a ready-made template for assessing the harmful effects of false and misleading advertising. For an advertisement to be actionable, it must contain false or misleading statements that are material, that deceive or are likely to deceive consumers, and that cause or are likely to cause harm to the plaintiff. ${ }^{109}$

Considering false advertising law raises questions about the propriety of the factors making up the de minimis framework. For example, a clear falsity requirement does not reflect false advertising's concern with misleading statements, which could be literally true or ambiguous but still induce consumers to reach false conclusions. ${ }^{110}$ In fact, "[c]onsumers are less likely to argue against associations they came up with themselves, and more likely to remember and act on them." 111 Additionally, reasonable reliance duplicates false advertisement's materiality factor while overemphasizing the fraud-like idea - not present in false advertising law — of "reasonable" reliance. Nor do the other factors in the de minimis test capture the reality of false advertising, which is not readily susceptible to neutralization and which can still be effective even if directed to buyers with knowledge of the subject matter. In short, in departing from the basics of false advertising law, the de minimis framework raises questions. ${ }^{112}$ Despite these shortcomings, because it represents the state of the law in many courts, I take the de minimis test as a given in this piece.

A case from the medical device industry, Lenox MacLaren Surgical Corp. v. Medtronic, ${ }^{113}$ provides one potential guidepost for analysis based on the de minimis approach. In that case, Lenox, a manufacturer of bone mills used in spinal-fusion surgery, ${ }^{114}$ entered into an agreement by which Medtronic distributed the product to hospitals. ${ }^{115}$ After the agreement broke down, Lenox alleged that Medtronic engaged in disparagement that

\footnotetext{
109 See Carrier \& Tushnet, supra note 102, at 7.

110 See, e.g., Hickson Corp. v. N. Crossarm Co., 357 F.3d 1256, 1260 (11th Cir. 2004); Fed. Trade Comm'n v. Roca Labs, Inc., 345 F. Supp. 3d 1375, 1386 (M.D. Fla. 2018).

111 Edward F. McQuarrie \& Barbara J. Phillips, Indirect Persuasion in Advertising: How Consumers Process Metaphors Presented in Structures and Words, ASs'N FOR CONSUMER RSCH., https://www.acrwebsite.org/web/acr-content/749/indirect-persuasion-in-advertising-how-consumersprocess-metaphors-presented-in-pictures-and-words.aspx\#: :text=Consumers\%20are\%20less\%20likely $\% 20$ to,remember\%20and\%20act $\% 20$ on\%20them.\&text=We\%20found $\% 20$ that $\% 20$ consumers $\% 20$ thou ght,difficult $\% 20$ stains $\% 20$ from\%20dishes\%E2\%80\%9D [https://perma.cc/486W-WMLR].

112 For additional critiques of the test, see Carrier \& Tushnet, supra note 102, at 13-20.

113762 F.3d 1114 (10th Cir. 2014).

114 Bone mills grind up bones to be used in surgery. See generally Med Device Monday: Bone Mills, ACKNOWLEDGE Reg. STRATEgIES (May 30, 2017), https://www.acknowledgers.com/blog/2017/5/29/med-device-monday-bone-mills [https://perma.cc/HWS2-FJTA].

115 Lenox, 762 F.3d at 1116.
} 
constituted monopolization by telling potential customers that its device was dangerous and helping to initiate a recall. ${ }^{116}$ Applying the six-factor test, the Tenth Circuit found that Lenox offered evidence to rebut the presumption of a de minimis impact on competition. ${ }^{117}$

The court's discussion of three of the six factors is instructive. ${ }^{118}$ For the fourth factor, whether the alleged statement was made to buyers without knowledge of the subject matter, the court found that "even sophisticated consumers [like hospitals and group purchasing organizations] would rely on Medtronic's false statements." 119 For the fifth factor, whether the false statement continued for prolonged periods, the court found that the continued listing of Lenox's device on the FDA's website as recalled was enough to show a prolonged period. ${ }^{120}$ And the court found the sixth factor, whether the plaintiff could show that it could not readily neutralize the disparaging statement, was satisfied from "worries involving malpractice liability," which resulted in "hospitals [being] unwilling to purchase" recalled products. ${ }^{121}$ The Lenox case offers a roadmap for how a plaintiff can satisfy this framework.

\section{Case-by-Case}

A third group of courts, led by the Third, Eighth, and D.C. Circuits, takes a case-by-case approach in assessing whether the alleged disparagement violates antitrust law. For example, the Third Circuit has explained that "anticompetitive conduct can include... making false statements about a rival to potential investors and customers" and that "defamation, which plainly is not competition on the merits, can give rise to antitrust liability, especially when it is combined with other anticompetitive acts." 122 Similarly, the D.C. Circuit has recognized that "fraudulent misrepresentations" are "well within" the universe of anticompetitive conduct. ${ }^{123}$ And the Eighth Circuit has explained that an alleged monopolist's "full frontal attack" that "(1) used false, misleading and deceptive advertising and (2) was directed at (a) consumers and (b) travel agents"

\footnotetext{
116 Id. at $1126-27$.

117 Id. at 1128 .

118 For the first three factors, the district court adopted the findings of an arbitration panel that had found that the conduct was false, was material, and induced reliance. Lenox MacLaren Surgical Corp. v. Medtronic, Inc., No. 10-cv-02139-RPM-BNB, 2013 WL 3179204, at *6 (D. Colo. June 21, 2013), rev'd on other grounds and aff'd on the grounds discussed, 762 F.3d 1114, 1130 (10th Cir. 2014).

119 Lenox, 762 F.3d at 1127.

$120 \mathrm{Id}$.

121 Id.

122 W. Penn. Allegheny Health Sys., Inc. v. UPMC, 627 F.3d 85, 109 n.14 (3d Cir. 2010).

123 Caribbean Broad. Sys., Ltd. v. Cable \& Wireless PLC, 148 F.3d 1080, 1087 (D.C. Cir. 1998).
} 
demonstrated an unreasonable restraint because of its "purpose of preventing any effective competition." 124

Courts applying the case-by-case approach have appreciated that anticompetitive conduct takes "too many different forms, and is too dependent upon context, for any court or commentator ever to have enumerated all the varieties." ${ }^{25}$ Under this approach, one relevant factor could be the role the conduct plays in a competitor's ability to finance high expenses. In one case, for example, the Third Circuit determined that false statements to investors about a competitor's financial health caused the rival to pay inflated financing costs on its debt and, in combination with other actions, demonstrated anticompetitive conduct sufficient to survive a motion to dismiss. ${ }^{126}$

A second factor that courts have analyzed under the case-by-case approach is the extent to which false statements lock in decision-making. In United States v. Microsoft Corp., for example, the D.C. Circuit found that deceptive statements to Java-based software developers about the interoperability of Windows-based systems with other platforms resulted in the inadvertent development of software compatible only with Windows and demonstrated anticompetitive conduct. ${ }^{127}$

Though courts have considered the two factors mentioned above, the case-by-case analyses apply a totality of the circumstances approach. By analyzing conduct as a whole without requiring a showing exceeding de minimis harm, this approach offers flexibility for biosimilar manufacturers bringing disparagement claims.

In sum, antitrust courts apply three very different frameworks when considering deception-based claims. The first, unjustifiable approach, abandons antitrust liability. The other two, considered more fully in the next Part, apply the strict standards of the de minimis framework and the more flexible standards of the case-by-case approach.

\footnotetext{
124 Int'1 Travel Arrangers, Inc. v. W. Airlines, Inc., 623 F.2d 1255, 1268 (8th Cir. 1980).

125 E.g., Caribbean Broad. Sys., 148 F.3d at 1087 (quoted in LePage's Inc. v. 3M, 324 F.3d 141, 152 (3d Cir. 2003)).

126 W. Penn. Allegheny, 627 F.3d at 109-10.

127253 F.3d 34, 76-77 (D.C. Cir. 2001). The FTC challenged similar conduct in its lawsuit against (and settlement with) Intel for its "deceptive acts and practices that misled consumers and the public." Complaint at 910 , In re Intel Corp., Dkt. No. 9341 (F.T.C. Dec. 16, 2009). In particular, the agency alleged that "Intel expressly or by implication falsely misrepresented that industry benchmarks reflected the performance of its [products] relative to its competitors' products" and "pressure[d] independent software vendors ... to label their products as compatible with Intel and not to similarly label with competitor's products' names or logs, even though these competitor microprocessor products were compatible." Id.
} 


\section{ANTITRUST VIOLATION}

Biologic manufacturers' disparagement of biosimilars can violate antitrust law. This Part shows how biologics typically have monopoly power. It then applies the two primary judicial approaches to the conduct, finding that monopolization is likely under both the de minimis and case-by-case approaches. ${ }^{128}$

As an initial matter, as applied to monopolists' deceptive conduct, antitrust law offers unique advantages over false advertising law. ${ }^{129}$ For example, as compared to false advertising law, antitrust offers more powerful remedies of treble damages, automatic (as opposed to exceptional) attorneys' fees,,$^{130}$ and injunctive relief preventing the behavior's continuation, ${ }^{131}$ as well as a more expansive universe of potential plaintiffs, all of which promise to provide robust deterrence.

\section{A. Monopoly Power}

A monopolization case consists of monopoly power and exclusionary conduct. ${ }^{132}$ The first element is monopoly power, which courts have defined as "the power to control prices or exclude competition." 133 Monopoly power can be shown in one of two ways. First, it can be proved indirectly by examining a defendant's market share along with barriers to entry that could entrench that market position. ${ }^{134}$ Courts regularly hold that a $90 \%$ market share supports monopoly power, with some courts finding a $75 \%$ share to be sufficient. ${ }^{135}$

\footnotetext{
128 The showing of an antitrust violation under Section 2 of the Sherman Act also provides support for the easier-to-satisfy standard of FTC Act Section 5, which targets unfair methods of competition. 15 U.S.C. $\S 45$ (2012).

129 See generally Carrier \& Tushnet, supra note 102, at 22-25 (explaining that antitrust offers more powerful remedies and contemplates a broader array of potential plaintiffs).

13015 U.S.C. $\S 1117$ (2012).

131 Carrier \& Tushnet, supra note 102, at 24 ("While a Lanham Act false advertising injunction generally is limited to the specific false claims that have been proven, an antitrust injunction could more generally target false advertising and marketwide harm to competition.").

132 E.g., United States v. Grinnell Corp., 384 U.S. 563, 570-71 (1966). This and the next two paragraphs are adapted from Michael A. Carrier, Sharing, Samples, and Generics: An Antitrust Framework, 103 CORNELL L. REV. 1, 21-22 (2017).

133 United States v. E.I. du Pont de Nemours \& Co., 351 U.S. 377, 391 (1956).

134 See Herbert HovenKamp, Federal Antitrust Policy: The LaW of COMPetition AND its PRACTICE 359-60 (5th ed. 2016).

135 Id. at 357.
} 
Second, a plaintiff can prove monopoly power directly, ${ }^{136}$ such as when a brand firm is able to "maintain the price of [a] drug . . . at supracompetitive levels without losing substantial sales ...."137 Direct proof of monopoly power can also consist of observable effects on the market such as a price increase or output reduction. ${ }^{138}$

The Supreme Court has held that a market can consist of a single product. ${ }^{139}$ Lower courts have also found that a single drug can constitute its own market, which has led naturally to the conclusion that a single drug can have monopoly power. ${ }^{140}$ Where potential purchasers have no alternative to using a drug, monopoly power is likely.

Biologics are likely to have monopoly power. There has been very limited entry of biosimilars in the United States. Biologics make up 7 of the top 10 highest-selling drugs in the country. ${ }^{141}$ And manufacturers charge astronomical prices, as much as hundreds of thousands of dollars per year for a product. ${ }^{142}$ Even though biologics make up less than $2 \%$ of the market, they represent $40 \%$ of prescription drug spending. ${ }^{143}$ Pfizer offered one example of monopoly power in its lawsuit against J\&J, claiming that J\&J's $10 \%$ price increase did not affect its $96 \%$ market share, with $90 \%$ of providers refusing to stock Pfizer's competing product. ${ }^{144}$

Given biologics' control over markets and ability to charge high prices without suffering losses, a plaintiff should be able to demonstrate that the

136 ABA Section of Antitrust Law, Antitrust Law DeVelopments 69-70 (7th ed. 2012) (noting that "direct proof has provided the basis for findings of substantial anticompetitive effects in some prominent cases").

${ }^{137}$ In re Nexium (Esomeprazole) Antitrust Litig., 968 F. Supp. 2d 367, 388 n.19 (D. Mass. 2013); see also In re Aggrenox Antitrust Litig., 94 F. Supp. 3d 224, 246 (D. Conn. 2015) (recognizing that direct evidence can establish market power).

138 Broadcom Corp. v. Qualcomm Inc., 501 F.3d 297, 307 (3d Cir. 2007).

139 Eastman Kodak Co. v. Image Tech. Servs., Inc., 504 U.S. 451, 481-82 (1992).

140 E.g., In re Nexium, 968 F. Supp. 2 d at 388 (rejecting defendants' claim that "other drugs may be used to treat heartburn"); In re Terazosin Hydrochloride Antitrust Litig., 352 F. Supp. 2d 1279, 1319 n.40 (S.D. Fla. 2005) (relevant market composed of brand and generic terazosin hydrochloride); In re Cardizem CD Antitrust Litig., 105 F. Supp. 2d 618, 680-81 (E.D. Mich. 2000) (holding that brand and generic versions of heart medication with chemical compound diltiazem hydrochloride constitute a single market).

141 Kyle Blankenship, The Top 20 Drugs by 2018 U.S. Sales, FierCe Pharma (Jun. 17, 2019, 7:00 AM), https://www.fiercepharma.com/special-report/top-20-drugs-by-2018-u-s-sales [https://perma.cc /7VBC-RVTK] (Humira, Revlimid, Enbrel, Rituxan, Opdivo, Eylea, Neulasta).

142 Sameer Awsare, The Price Is Wrong, Permanente Med. (Feb. 19, 2019), https://permanente.org/the-price-is-wrong/ [https://perma.cc/66M6-FADB].

143 Remarks from FDA Commissioner, supra note 1.

144 Pfizer Inc. v. Johnson \& Johnson, 333 F. Supp. 3d 494, 499-500 (E.D. Pa. 2018). 
products have monopoly power. ${ }^{145}$ Having satisfied monopoly power, the next element is exclusionary conduct. As discussed above, ${ }^{146}$ the Fifth and Seventh Circuits would not find liability under the first approach. But that is only because they abandon antitrust analysis. That is not a justifiable approach. Disparagement could cement a biologic's status as an unchallenged monopolist. And as confirmed by the various barriers to entry discussed above, ${ }^{147}$ the biologic would not easily lose that monopoly position.

\section{B. De Minimis}

The Second, Sixth, Ninth, Tenth, and Eleventh Circuits apply the de minimis framework to deception-based conduct. As discussed above, ${ }^{148}$ courts applying this framework presume that the exclusionary effects of disparagement are de minimis. The plaintiff can rebut such a presumption by showing that the alleged anticompetitive conduct is (1) clearly false, (2) clearly material, (3) clearly likely to induce reasonable reliance, (4) made to buyers without knowledge of subject matter, (5) continued for prolonged periods, and (6) not readily susceptible to neutralization or other offsets by rivals. ${ }^{149}$ The remainder of this Section applies the framework. ${ }^{150}$

The first factor requires clear falsity. It is unclear exactly what counts as "clearly false." But the relevant underlying law, false advertising, targets not only false, but also misleading, conduct. ${ }^{151}$ And, given that the FTC is the government agency most directly focused on challenging or misleading deceptive conduct, its analysis is particularly instructive. In a policy statement, the FTC explained that deception can involve "omission of material information, the disclosure of which is necessary to prevent the claim ... from being misleading." 152 Ensuring a robust interpretation, the FTC made clear that when a seller's representation "conveys more than one meaning to reasonable consumers, one of which is false, the seller is liable

\footnotetext{
145 Even easier to satisfy would be an attempted monopolization claim, which requires a plaintiff to show that "(1) the defendant has engaged in predatory or anticompetitive conduct with (2) a specific intent to monopolize and (3) a dangerous probability of achieving monopoly power." Spectrum Sports, Inc. v. McQuillan, 506 U.S. 447, 447 (1993).

146 See supra Section III.A.

147 See supra Section II.C.

148 See supra note 106 and accompanying text.

149 See supra note 106 (listing cases applying this framework).

${ }^{150}$ For a critique of the test, see supra notes 109-112 and accompanying text.

15115 U.S.C. $\$ 1125(\mathrm{a})(1)$ (B) (2012).

152 FTC Policy Statement ON Deception 2 (Oct. 14, 1983), https://www.ftc.gov/system/files/documents/public_statements/410531/831014deceptionstmt.pdf [https://perma.cc/7B99-NREQ].
} 
for the misleading interpretation." 153 "[I]t can be deceptive," the FTC explained, "to tell only half the truth, and to omit the rest." 154 Such a situation "may occur where a seller fails to disclose qualifying information" needed to prevent an "affirmative statement[] from creating a misleading impression." 155

These types of omissions and half-truths have appeared in the biologic setting. Genentech, Amgen, and Janssen each have made assertions that implied differences between biologics and biosimilars, warning that the products were "not identical," that "patients may react differently" to biosimilars, that biologics "cannot be copied exactly," that switches "carr[y] risks, given that no two biologic medicines are identical," that "[s]witching drugs is not a good idea if your medicine is working for you," and that a failure to achieve interchangeability threatens safety. ${ }^{156}$ At a minimum (and applying a conservative analysis), these assertions result in at least one interpretation to a reasonable consumer that there are clinically meaningful differences between the biologic and the biosimilar. But this innuendo is false. And to the sophisticated actors at the biologic companies, this is not likely to be an oversight. ${ }^{157}$

Turning to the second factor, the statements would be clearly material. The FTC has defined a "material" misrepresentation as "one which is likely to affect a consumer's choice" of product. ${ }^{158}$ Such an assertion targets "information that is important to consumers." 159 The FTC presumes that even implied claims "are material if they pertain to the central characteristics of the product, such as its safety. ..." ${ }^{160}$ Similarly, "omissions [are] material if they significantly involve health. ..."161 To state the obvious, denigrating a biosimilar product is material. It is hard to imagine a statement more material than one warning of health concerns with a competitor's product.

Third, biologic manufacturers' statements would clearly be likely to induce reasonable reliance. A representation about a biosimilar's safety is exceedingly likely to discourage the patient from purchasing the product. At

153 Id. at 3.

154 In re Int'l Harvester Co., 104 F.T.C. 949, 1057 (1984).

155 Id.

156 See supra note 48 and accompanying text.

157 See Findings of Fact and Conclusions of Law at 52, Fed. Trade Comm'n v. AbbVie Inc., No. 145151 (E.D. Pa. June 29, 2018) ("Since these experienced patent attorneys filed objectively baseless infringement lawsuits, it is reasonable to conclude that they intended the natural and probable consequences of acts they knowingly did.").

158 FTC POLICY STATEMENT ON DECEPTION, supra note 152, at 5.

$159 \mathrm{Id}$.

160 In re Int'l Harvester, 104 F.T.C. at 1057.

161 FTC POLICY STATEMENT ON DECEPTION, supra note 152, at 5. 
the same time, doctors also would be less likely to prescribe the biosimilar and payors would be less likely to reimburse biosimilars. And not only would there be reliance, but it would also be reasonable given the unparalleled consequences of taking unsafe medications. ${ }^{162}$

Fourth, the statements would be made to buyers without knowledge of the subject matter. Doctors rely on the pharmaceutical industry, "the most typical source of information about biosimilars," with prescriptions based on information disseminated by the industry. ${ }^{163}$ In fact, doctors "report being unsure how to go about explaining biosimilars to patients, which further restricts their use." 164 This is unfortunate, as "positive framing can improve patients' perceptions of biosimilars and increase their hypothetical willingness to switch to a biosimilar from a biologic treatment." 165 Perhaps it is not a surprise then that patients "hold concerns about biosimilars, particularly relating to safety, efficacy, manufacturing and clinical trials that need to be addressed to improve acceptability." 166

The Lenox case discussed above ${ }^{167}$ supports a finding that the fourth factor is satisfied. That court found that "even sophisticated consumers [like hospitals and group purchasing organizations] would rely on false statements." 168 Here, it does not take a lot in the way of innuendo to dissuade patients from taking, and doctors from prescribing, biosimilars. Again, doctors rely on the pharmaceutical industry as "the most typical source of information about biosimilars." 169 Given doctors' obligations to keep abreast of industry standards and avoid prescribing products with safety concerns, it is concerning that "the information disseminated by the pharmaceutical industry affects [doctors'] prescription decisions." 170

\footnotetext{
162 Such anticipated reliance further demonstrates the shortcomings of the Fifth Circuit analysis described above, see supra Section III.A, that "it will often be difficult to determine whether ... false statements induced reliance by consumers and produced anticompetitive effects, or whether the buyer attached little weight to the statements and instead regarded them as biased and self-serving." Retractable Techs., Inc. v. Becton Dickinson \& Co., 842 F.3d 883, 895 (5th Cir. 2016).

163 Physicians Hold a Largely Positive View of the Uptake of Biosimilars, FIMEA (May 15, 2019), https://www.fimea.fi/web/en/-/physicians-hold-a-largely-positive-view-of-the-uptake-of-biosimilars [https://perma.cc/LQX8-5HGN].

164 Chiara Gasteiger, Nicola Dalbeth \& Keith Petrie, The Effects of Message Framing on Patients' Perceptions and Willingness to Change to a Biosimilar in a Hypothetical Drug Switch, ARTHRITIS CARE \& RES. (2019) (manuscript at 4) (on file with author).

165 Id. at 16.

166 Id. at 3.

167 See supra notes 113-117 and accompanying text.

168 Lenox MacLaren Surgical Corp. v. Medtronic, Inc., 762 F.3d 1114, 1127 (10th Cir. 2014).

169 Physicians Hold a Largely Positive View of the Uptake of Biosimilars, supra note 163.

${ }^{170} \mathrm{Id}$.
} 
Fifth, the statements' effect would likely last for prolonged periods. In the Lenox case, the court found that the continued listing of Lenox's device on the FDA's website as recalled was enough to show a prolonged period. ${ }^{171}$ Biologic companies have control over the market, and this factor would seem to be easily satisfied as they would be likely to promulgate the assertions for lengthy periods of time to maintain their monopolies.

Sixth, the plaintiff would not be able to readily neutralize the disparaging statements. Once a safety concern is raised, it is particularly difficult to rebut. Consumers taking, and doctors prescribing, follow-on products that are not exactly the same as the original would tend to shy away from products with safety concerns. Given the dire consequences of drugs operating differently, it is natural to err on the side of avoiding biosimilars.

At its core, the Lenox court emphasized the effect of potential liability concerns in secondary markets. Similarly, the central issue confronting doctors in prescribing biosimilars would be whether they are convinced the product operates in a similar manner to the biologic, or instead threatens patients' safety or diminishes efficacy of treatment. Lenox provides a useful guidepost to future courts in emphasizing liability fears as a factor that can overcome the presumption of a de minimis impact on competition.

In short, a plaintiff challenging a biologic firm's disparagement of a biosimilar would likely satisfy the second through sixth factors of the de minimis test. A court applying a high standard for the first factor might find that the conduct, although misleading, is not "clearly false." In applying the factors, courts should consider false advertising law and the FTC's consideration of the issue, which would recommend liability. And, at a minimum, for courts that do not require each of the factors to be satisfied, ${ }^{172}$ liability would most likely be found based on the presence of at least five of the six factors.

\section{Case-by-Case}

The case-by-case approach would be even more likely to find liability. By analyzing conduct as a whole without requiring a showing exceeding de minimis harm, the case-by-case approach offers flexibility that increases the likelihood of successful disparagement claims. This flexible framework would allow courts to consider the regulatory setting and the FDA's lack of success in fostering robust biosimilar competition. It would also recognize the irreversible and lasting effects of locking new patients into biologics because they do not trust biosimilars. And, finally, it would consider the

\footnotetext{
171 Lenox, 762 F.3d at 1127.

172 See supra note 108 and accompanying text.
} 
effects of disparagement in cementing the multiple barriers to entry that entrench the biologic's power.

Cases that have applied this approach offer building blocks for liability. Like the Third Circuit case mentioned earlier involving false statements impacting a rival's financing costs, ${ }^{173}$ disparagement could adversely affect a biosimilar company's ability to finance already-high expenses. Moreover, like the D.C. Circuit case, which found that deceptive statements resulted in anticompetitive conduct, ${ }^{174}$ false statements could lock in physician decisionmaking. ${ }^{175}$

The case-by-case approach could also allow plaintiffs to demonstrate that parties with monopoly power have satisfied the elements of the false advertising offense. ${ }^{176}$ Given the "near certainty" of anticompetitive effects in this setting, Professor Rebecca Tushnet and I have suggested that courts should adopt a presumption of monopolization when the elements at the core of false advertising law are satisfied. ${ }^{177}$

Through its less regimented analysis, the case-by-case approach increases the likelihood that biologic companies would be found liable for monopolistic conduct. The approach would more likely consider the factors highlighted in Part II above (such as significant barriers to entry and the FDA's ineffectiveness in bringing about robust biosimilar competition), allowing plaintiffs to show how these factors exacerbate anticompetitive effects of increased price and reduced output, and it would enable plaintiffs to illustrate how disparagement offers no legitimate procompetitive justifications.

\section{CONCLUSION}

Biologics are the wave of the future, promising to unleash revolutionary health benefits. But their price tag is staggering. And if biologic manufacturers can stifle more affordable biosimilars in their cradle by ominously implying false safety concerns, patients will suffer. Recognizing an antitrust cause of action for disparagement promises to enhance competition and help U.S. consumers afford life-saving medicines.

173 See supra Section III.C.

174 United States v. Microsoft Corp., 253 F.3d 34, 76-77 (D.C. Cir. 2001).

175 See Thomas F. Cotter, On Unknown Opportunities and Perils: Reflections on Carrier and Minniti's “Biologics: The New Antitrust Frontier," 2018 U. ILL. L. REV. OnLINE 72,79 (2018) ("The fact that some courts have appeared (perhaps overly) skeptical of such claims should not distract others from applying mainstream antitrust principles when the facts so require.”).

176 See supra text accompanying notes 173-175.

177 Carrier \& Tushnet, supra note 102, at 29. 